\title{
Dispersal pattern of glass eel stage of Anguilla australis revealed by otolith growth increments
}

\author{
Jen-Chieh Shiao' ${ }^{1}$, Wann-Nian Tzeng ${ }^{1, *}$, Adrian Collins ${ }^{2}$, Donald John Jellyman ${ }^{3}$ \\ ${ }^{1}$ Department of Zoology, National Taiwan University, 1, Sec 4, Roosevelt Rd, Taipei, Taiwan 10617, Republic of China \\ ${ }^{2}$ Bribie Island Aquaculture Research Centre, 144 North Street Woorim, Bribie Island, Queensland 4057, Australia \\ ${ }^{3}$ National Institute of Water and Atmospheric Research, PO Box 8602, Christchurch, New Zealand
}

\begin{abstract}
Glass eels of the Australasian shortfin eel Anguilla australis (Richardson 1841) were collected from 6 Australian and 2 New Zealand estuaries. Their ages were estimated by counting daily growth increments in the otoliths. According to mean size and age at capture, the glass eels were classified into a northern Australia group or a southern Australia and New Zealand group. The mean length of glass eels increased from $47.6 \pm 2.11 \mathrm{~mm}$ in northern estuaries to $59.2 \pm 3.61 \mathrm{~mm}$ in the south. The mean age of glass eels at capture was significantly lower in the north $(214 \pm 14.6$ to $223 \pm 17.7 \mathrm{~d})$ than in the south $(243 \pm 19.7$ to $261 \pm 22.4 \mathrm{~d})(\mathrm{p}<0.05)$. In contrast, the otolith growth rate was greater in the north than in the south. The dramatic increase in increment width and the decline of the Sr:Ca ratios in otoliths were used to determine the timing of metamorphosis from leptocephalus to glass eel stage. The mean ages of leptocephali at metamorphosis were significantly lower in the north $(160 \pm 14.2$ to $161 \pm 12.6 \mathrm{~d})$ than in the south $(168 \pm 14.5$ to $189 \pm 16.9 \mathrm{~d})$, indicating that faster-growing and earlier-metamorphosed leptocephali recruited to northern Australia and slow-growing and late-metamorphosed leptocephali recruited to southern Australia and New Zealand. In addition, based on current direction and the similarity in age of leptocephali at metamorphosis, age at capture and the period between metamorphosis and estuarine arrival, New Zealand glass eels are unlikely to be transported across Tasman Sea from southern Australia by the East Australian Current, and must reach their destination via a different route(s).
\end{abstract}

KEY WORDS: Australasian shortfin eel · Otolith · Metamorphosis · Geographic cline Resale or republication not permitted without written consent of the publisher

\section{INTRODUCTION}

The Australasian shortfin eel Anguilla australis (Richardson, 1841) is a temperate catadromous fish, widely found in the rivers of southeast Australia, Tasmania, New Caledonia, Norfolk Island, Lord Howe Island and New Zealand (Ege 1939). Although previously described by Schmidt (1928) and Ege (1939) as 2 subspecies (A. australis australis the Australian subspecies, and A. australis schmidtii the New Zealand subspecies), a recent review based on mitochondrial DNA concluded that this designation was invalid and recommended

*Corresponding author: E-mail: wnt@ccms.ntu.edu.tw that the 2 subspecies be merged into a single species (Dijkstra \& Jellyman 1999). The spawning grounds of A. australis is unknown, but possible sites have been suggested as near New Caledonia (Schmidt 1928), between Fiji and Tahiti (Castle 1963, Aoyama et al. 1999), or further west than this at 150 to $170^{\circ} \mathrm{W}$ and 5 to $15^{\circ} \mathrm{S}$ (Jellyman 1987). Despite the uncertainty about its spawning grounds, it is believed that, like larvae of other temperate eels (A. anguilla, A. rostrata and A. japonica), larvae of the Australasian shortfin eel may drift with oceanic currents from their spawning grounds to the continents (Sloane 1984, Jellyman 1987, Arai et al. 1999c).

Since the daily growth increment in otoliths was discovered by Pannella (1971), this ageing technique, 
together with the microchemistry analysis of otoliths, has been extensively used to study the early life history of freshwater eels (Tzeng 1990, Otake et al. 1994, Tzeng \& Tsai 1994, Arai et al. 1999a,b,c). Arai et al. (1999c) recently determined the age of Anguilla australis on a daily basis and found that the glass eels recruited to Australia $(208 \pm 17.4$ d) were ca 20 to $30 \mathrm{~d}$ younger than those recruited to New Zealand $(232 \pm 19.8 d$ western coast, $237 \pm 20.0$ d eastern coast). They considered that the difference in age of glass eels arriving at the coasts of Australia and New Zealand might be due to differences in the migratory routes taken by these 2 stocks (Arai et al. 1999c), but had insufficient data to determine the actual routes. Comparing the daily age of glass eels at metamorphosis and upon estuarine arrival across their dispersal range is a useful technique to help determine the migratory routes of eel larvae (Cheng \& Tzeng 1996, Wang \& Tzeng 1998, 2000).

The present study examines the microstructure and microchemistry of glass eel otoliths to determine the ages of leptocephali at metamor-

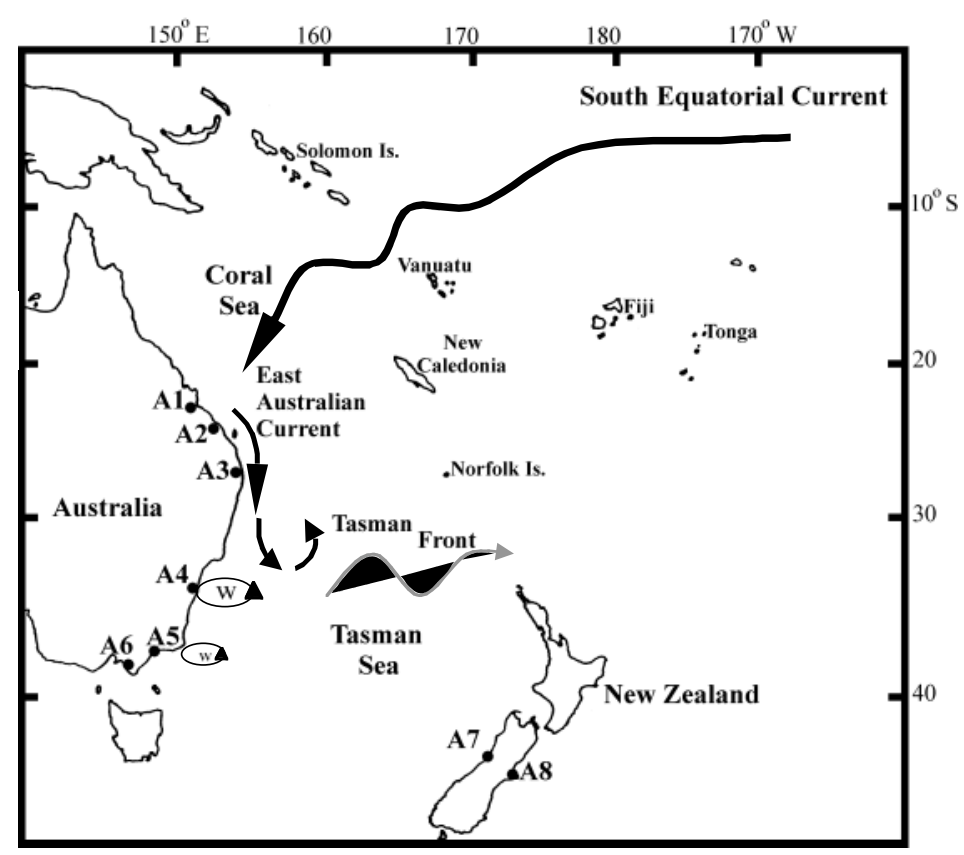

Fig. 1. Sampling sites of Anguilla australis. A1: Fitzroy River; A2: Kolan River; A3: Albert River; A4: Port Hacking River; A5: Brodribb River; A6: Tarwin River; A7: Arahura River; A8: Purau Stream phosis and of glass eels upon arrival in the Australian and New Zealand estuaries. From a consideration of the size and age of the glass eels, we proceed to consider possible migratory drifting routes from the oceanic spawning grounds to Australia and New Zealand.

\section{MATERIALS AND METHODS}

Glass eels of Anguilla australis were collected from 6 estuaries on the eastern coasts of Australia in 1997, 1998 and 1999, and from 2 estuaries on the eastern and western coasts of New Zealand in 1996 (Fig. 1). The sampling sites almost covered the dispersal range of $A$. australis along the eastern coast of Australia, except for Tasmania. Table 1 lists the sampling sites, dates and sample size of the glass eels. The glass eels recruiting to Australian estuaries were caught by a Japanese Hell net $(12 \mathrm{~m} \times 12 \mathrm{~m})$ and those from New Zealand were sampled using an electric shocker. All glass eels collected were preserved in 95\% alcohol. Pigmentation stages were assessed according to pigment distribution on the body surface (Strubberg 1913).

Table 1. Anguilla australis sampling sites, dates and sample sizes collected from 6 Australian estuaries (Sites A1 to A6) and 2 New Zealand estuaries (Sites A7 to A8) (sites are shown in Fig. 1). Numbers in parentheses: numbers of specimens for which ages were determined

Total lengths were measured to the nearest $0.01 \mathrm{~mm}$ before sagittal otoliths were extracted for microchemistry analysis and age determination. The otoliths were embedded in Epofix resin, ground and polished until the core was exposed on the surface. For electron probe microanalysis (Joel JXA-8800M), the polished otoliths were coated with a layer of carbon under a high-vacuum evaporator. Strontium (Sr) and calcium (Ca) concentrations were measured each 2 or $10 \mu \mathrm{m}$ from the core to the edge of the otoliths with an electron beam of 2 or $10 \mu \mathrm{m}$ diameter. Accelerating voltage was set at $15 \mathrm{kV}$ and probe current at 3 or $5 \mathrm{nA}$. The

\begin{tabular}{|lclr|}
\hline Sampling site & $\begin{array}{c}\text { Distance } \\
\text { upstream (km) }\end{array}$ & Sampling date & $\begin{array}{r}\text { Sample } \\
\text { size (n) }\end{array}$ \\
\hline Australia & & & \\
$\quad$ Fitzroy River (A1) & 53 & 7 Aug, 1998 & $50(29)$ \\
Kolan River (A2) & 14.5 & 1 \& 16 Jul, 1997 & $70(33)$ \\
Albert River (A3) & 42 & 2 May \& 2 Jun, 1997 & $142(27)$ \\
Port Hacking River (A4) & 12 & 17 Jun \& 18 Jul, 1999 & $35(26)$ \\
Brodribb River (A5) & 4.6 & 11 Jul, 11 Aug \& 5 Sep, 1997 & $138(35)$ \\
Tarwin River (A6) & 14 & 18 Jul, 21 Aug \& 19 Sep, 1997 & $137(39)$ \\
New Zealand & & & \\
Arahura River (A7) & & 22 Aug, 1996 & $25(22)$ \\
Purau Stream (A8) & & 29 Aug, 1996 & $24(19)$ \\
\hline
\end{tabular}


(a)
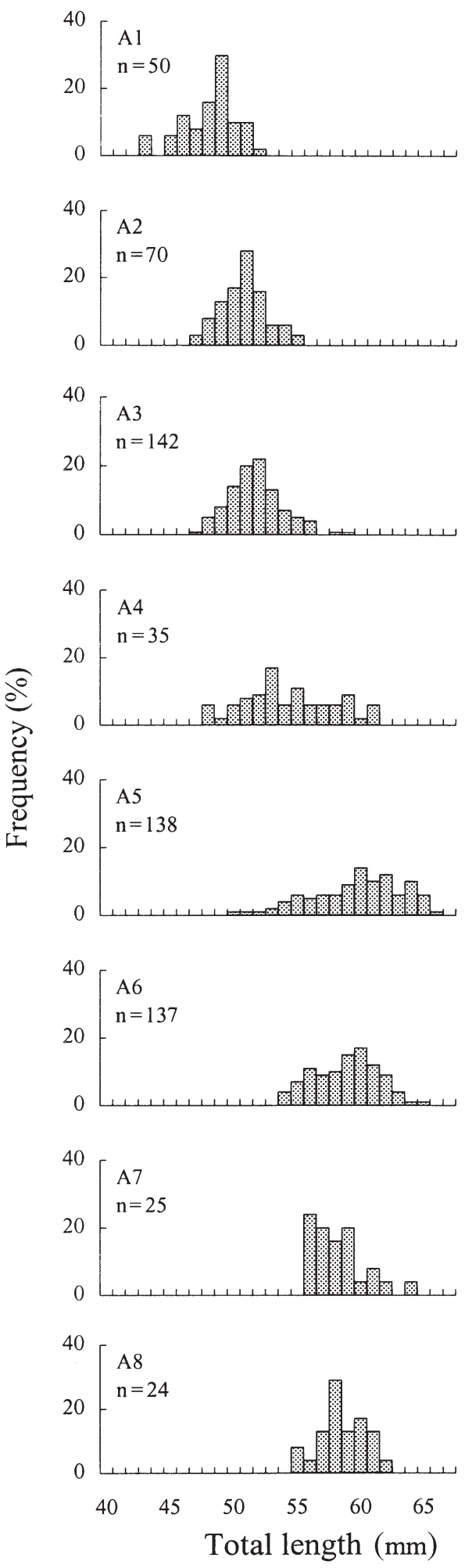

\section{(b)}
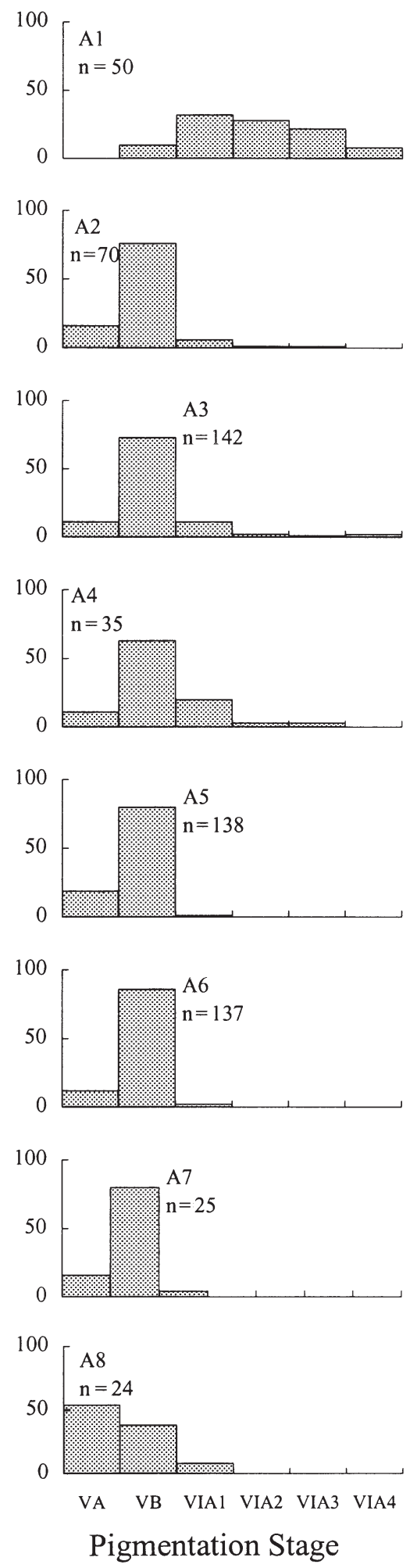

Fig. 2. Anguilla australis. Frequency distribution of total length (a) and pigmentation stages (b) of glass eels collected from the 8 estuaries (Sites A1 to A8 are shown in Fig. 1). $\mathrm{n}=$ sample size

peak of Sr was counted for $120 \mathrm{~s}$, and background was measured for $20 \mathrm{~s}$ on each side, while the peak of Ca was counted for $20 \mathrm{~s}$ with $10 \mathrm{~s}$ for each background. $\mathrm{SrTiO}_{3}$ and $\mathrm{CaMoO}_{4}$ were used as standards for the quantitative analysis of $\mathrm{Sr}$ and $\mathrm{Ca}$ respectively. The otoliths were then repolished to remove the carbon layer, etched with $0.05 \mathrm{M} \mathrm{HCl}$ for $15 \mathrm{~s}$, dried in the oven, and coated with a layer of gold for SEM observation. Photographs were taken at a magnification of $2000 \times$ for counting the daily growth increments.

The timing of metamorphosis from leptocephali to glass eels was determined from the drastic increase of increment width coinciding with the decrease in $\mathrm{Sr}$ :Ca ratios (Otake et al. 1994, Tzeng \& Tsai 1994, Arai et al. 1997, Wang \& Tzeng 1998, Arai et al. 1999a,b,c). However, some checks were formed in the otoliths after the glass eels entered the estuaries. The innermost check was called the 'freshwater mark' and the growth increments after this mark were probably deposited during the time that theglass eels were in the estuary (Kawakami et al. 1998). Accordingly, the otolith radii were relegated to 3 stages: $\mathrm{R}_{\mathrm{m}}$ (leptocephalus stage), $R_{s}$ (glass eel stage from metamorphosis to estuarine arrival) and $R_{e}$ (glass eel stage when present in the estuary) were measured on the SEM pictures. Age at capture $\left(T_{t}\right)$, age at metamorphosis of the leptocephali $\left(T_{m}\right)$, the period between metamorphosis and estuarine ar$\operatorname{rival}\left(\mathrm{T}_{\mathrm{s}}\right)$, and the duration of the period spent in the estuary before collection $\left(\mathrm{T}_{\mathrm{e}}\right)$ were estimated from the counts of daily growth increments in the corresponding radii. Information on the duration of the yolk-sac stage of Australasian shortfin eel is not available, so $T_{t}$ and $T_{m}$ could not be adjusted for the period of the yolk-sac stage as for the Japanese and American eels (5 d yolk-sac stage: Cheng \& Tzeng 1996, Wang 
\& Tzeng 1998). To calculate the otolith growth rates of leptocephalus and glass eel stages, the otolith radius of each stage was divided by the corresponding age. The hatching dates of the glass eels were back-calculated from their ages at capture and the sampling dates. Because of preservation effects, the growth increments at the otolith edge, approximately $15 \mu \mathrm{m}$, could not be revealed clearly in some New Zealand samples. Therefore, to avoid an underestimate in daily age, the growth increments of the damaged area were estimated from the otolith growth rate and radius in such cases.

The homogeneity of the total length and daily age of glass eels, as well as their otolith radius and growth rate, was tested among estuaries. If the data were normally distributed with equal variance, then Tukey multiple comparison was used; otherwise, a Kruskal-Wallis 1-way ANOVA test on ranks was used.

\section{RESULTS}

\section{Total length and pigmentation stage}

The total lengths of glass eels of Anguilla australis collected from the 8 estuaries ranged from 42.8 to $65.5 \mathrm{~mm}$ and showed a geographic cline that increased from north to south (Fig. 2a). Based on size, glass eels were classified into 2 groups: a smaller northern group (Sites A1 to A3, mean $47.6 \pm 2.11$ to $51.2 \pm 3.14 \mathrm{~mm}$ ) and a larger southern group (Sites A5 to A8, mean 57.8 \pm 2.02 to $59.2 \pm 3.61 \mathrm{~mm})$, with Site A4 $(53.9 \pm 3.56 \mathrm{~mm})$ being a median group (Table 2).

The pigmentation stages of glass eels collected from the 8 estuaries were dominated by Stages VA and VB, except at Site A1 which yielded advanced pigmentation stages, VIA1 to VIA4 (Fig. 2b). The glass eels of Stages VA and VB were believed to be the new recruits in the estuary. Arai et al. (1999c) indicated that glass eels kept in freshwater for $10 \mathrm{~d}$ after collection develop to Stages VIA1 to VIA4. This suggests that

Table 2. Anguilla australis. Homogeneity test (HG) for total length (mean $\pm \mathrm{SD}$ ) of glass eels collected from the 8 estuaries (A1 to A8). Asterisks shared between estuaries indicate they belong to the same homogeneous group $(\mathrm{p}<0.05) . \mathrm{n}=$ sample size

\begin{tabular}{|lrcc|}
\hline Sites & $\mathrm{n}$ & Mean $\pm \mathrm{SD}$ & HG \\
\hline A1 & 50 & $47.6 \pm 2.11$ & $*$ \\
A2 & 70 & $50.2 \pm 1.77$ & ${ }^{* *}$ \\
A3 & 142 & $51.2 \pm 3.14$ & ${ }^{* *}$ \\
A4 & 35 & $53.9 \pm 3.56$ & ${ }^{* *}$ \\
A7 & 25 & $57.8 \pm 2.02$ & ${ }^{* *}$ \\
A8 & 24 & $58.0 \pm 1.91$ & $*$ \\
A6 & 137 & $58.4 \pm 2.49$ & $*$ \\
A5 & 138 & $59.2 \pm 3.61$ & $*$ \\
\hline
\end{tabular}

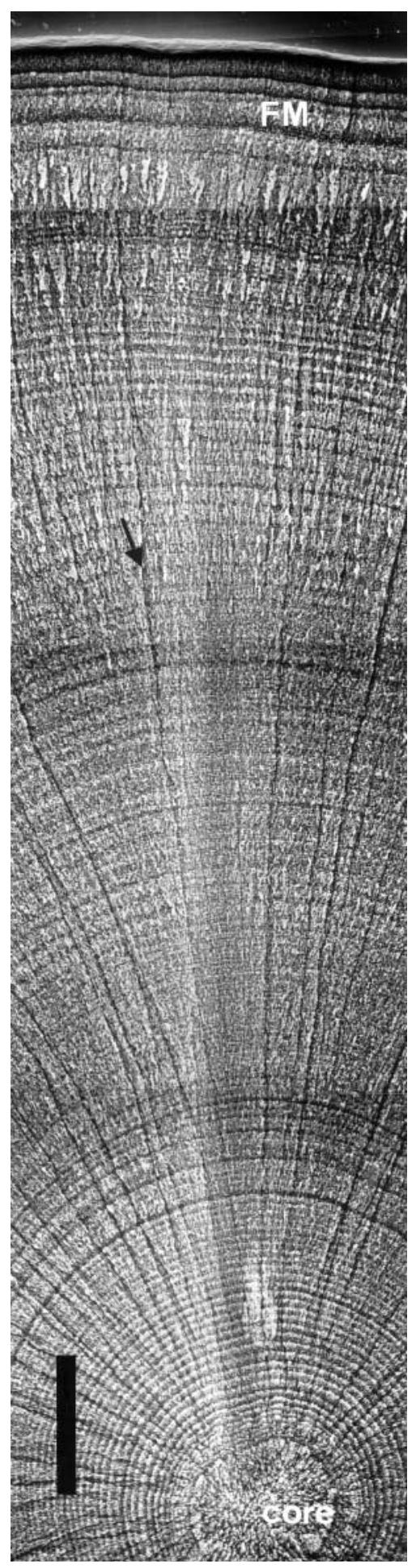

Fig. 3. Anguilla australis. Daily growth increments in the otolith of a $53.95 \mathrm{~mm}$ total length glass eel collected from Brodribb River (Site A5), Australia. The burned line from the core to the edge of the otolith indicates where Sr and Ca concentration were measured using EPMA. Arrow indicates the abrupt increase of increment width and the appearance of radial aragonite crystals coinciding with decline of $\mathrm{Sr}: \mathrm{Ca}$ ratios. FM: freshwater mark. Scale bar $=15 \mu \mathrm{m}$ 

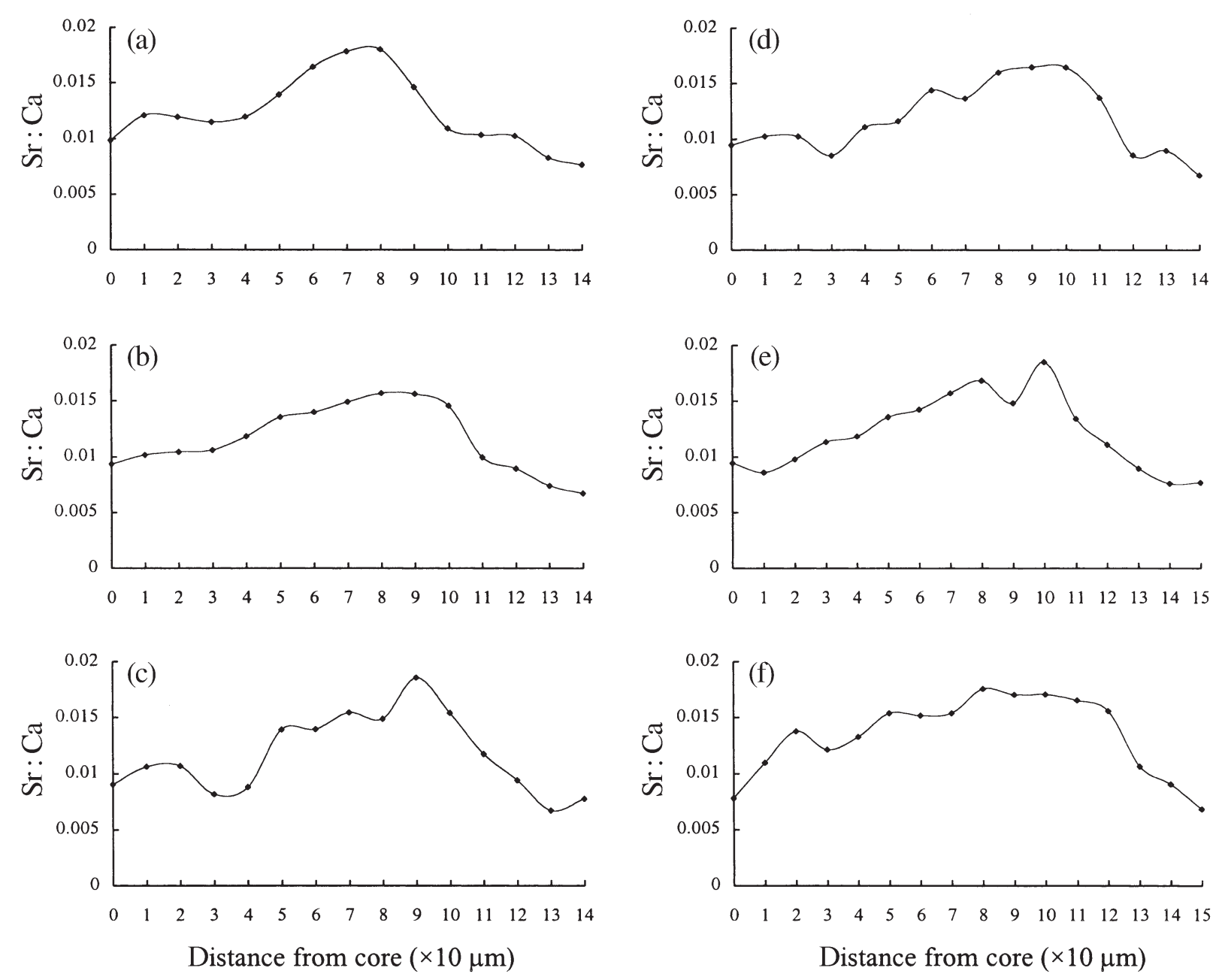

Fig. 4. Anguilla australis. Sr:Ca ratios measured along life history transects of glass eel otoliths from the core to the edge. The glass eels were from Albert River $(\mathrm{a}-\mathrm{c})$ and from Brodribb River $(\mathrm{d}-\mathrm{f})$

glass eels from Site A1 may remain in the estuary longer than those at other locations.

\section{Otolith microstructure and $\mathrm{Sr}: \mathrm{Ca}$ ratios}

No clear daily growth increment was discernible in the otolith core. Beyond the core, concentric daily growth increments were visible. Increment width increased gradually as the glass eels continued to grow, reaching a peak at ca $0.8 \mu \mathrm{m}$ approximately 40 to $50 \mathrm{~d}$ after hatching and then decreasing gradually to ca $0.2 \mu \mathrm{m}$. Then, the aragonite crystal arrangement changed from a concentric to a radial form while increment width abruptly increased to $1-1.5 \mu \mathrm{m}$, decreasing again at the edge of the otolith (Fig. 3).

The otolith Sr:Ca ratios along life-history transects were similar among individuals (Fig. 4), being approximately $10 \times 10^{-3}$ in the otolith core and increasing gradually with increasing otolith radius to a maximum of about $18 \times 10^{-3}$, corresponding to the area where the increment width was narrowest. The Sr:Ca ratios then decreased abruptly to a minimum of approximately 6 to $7 \times 10^{-3}$, again at the edge of the otoliths (Fig. 4). The decrease in the $\mathrm{Sr}$ Ca ratio coincided with a drastic increase in increment width. The simultaneous changes in increment width and $\mathrm{Sr}$ :Ca ratio indicates metamorphosis from the leptocephalus to the glass eel stage (Otake et al. 1994, Tzeng \& Tsai 1994, Arai et al. 1997, Wang \& Tzeng 1998, Arai et al. 1999a,b,c).

\section{Ages at metamorphosis, estuarine arrival and duration of stay in the estuaries}

The mean ages of the glass eels ranged from 180 to $326 \mathrm{~d}$ at capture $\left(\mathrm{T}_{\mathrm{t}}\right)$, from 130 to $245 \mathrm{~d}$ at metamorphosis $\left(\mathrm{T}_{\mathrm{m}}\right)$, from 15 to $113 \mathrm{~d}$ between metamorphosis and 
Table 3. Anguilla australis. Homogeneity test $(\mathrm{HG})$ for age of glass eels arriving at the 8 estuaries $\left(\mathrm{T}_{\mathrm{t}}\right)$, age of leptocephalus at metamorphosis $\left(\mathrm{T}_{\mathrm{m}}\right)$, time between metamorphosis and arrival at the estuaries $\left(\mathrm{T}_{\mathrm{s}}\right)$, and residence time in the estuary before collection $\left(\mathrm{T}_{\mathrm{e}}\right)$. Asterisks shared between estuaries indicate they belong to the same homogeneous group $(p<0.05)$. Sample size for each site is shown in parentheses in Table 1. nt: data excluded from homogeneity test because microstructure of otolith edge was damaged and freshwater mark was not discernible

\begin{tabular}{|c|c|c|c|c|c|c|c|c|c|c|c|}
\hline Site & $\begin{array}{c}\mathrm{T}_{\mathrm{t}} \\
\text { Mean } \pm \mathrm{SD}\end{array}$ & HG & Site & $\begin{array}{c}\mathrm{T}_{\mathrm{m}} \\
\text { Mean } \pm \mathrm{SD}\end{array}$ & HG & Site & $\begin{array}{c}\mathrm{T}_{\mathrm{s}} \\
\text { Mean } \pm \mathrm{SD}\end{array}$ & HG & Site & $\begin{array}{c}\mathrm{T}_{\mathrm{e}} \\
\text { Mean } \pm \mathrm{SD}\end{array}$ & $\mathrm{HG}$ \\
\hline A2 & $214 \pm 14.6$ & * & A2 & $160 \pm 12.0$ & * & A3 & $43 \pm 10.6$ & * & A5 & $6 \pm 7.5$ & * \\
\hline A3 & $217 \pm 16.6$ & * & A1 & $160 \pm 14.2$ & * & A1 & $45 \pm 11.5$ & * & $\mathrm{A} 2$ & $8 \pm 8.7$ & * \\
\hline A1 & $223 \pm 17.7$ & * & A3 & $161 \pm 12.6$ & $*$ & $\mathrm{~A} 2$ & $46 \pm 10.5$ & * & A4 & $8 \pm 8.5$ & * \\
\hline A4 & $243 \pm 19.7$ & * & A4 & $168 \pm 14.5$ & $* *$ & A5 & $57 \pm 12.9$ & $*$ & $\mathrm{~A} 6$ & $9 \pm 8.8$ & $*$ \\
\hline A8 & $246 \pm 14.5$ & * & A8 & $180 \pm 8.6$ & $* *$ & A6 & $63 \pm 14.6$ & $* *$ & A3 & $12 \pm 7.9$ & $* *$ \\
\hline A5 & $247 \pm 23.9$ & * & A5 & $183 \pm 20.8$ & $* *$ & A4 & $67 \pm 13.1$ & * & A1 & $19 \pm 10.9$ & * \\
\hline A7 & $258 \pm 19.7$ & * & A7 & $188 \pm 11.9$ & * & A7 & $70 \pm 15.1^{a}$ & nt & & & nt \\
\hline A6 & $261 \pm 22.4$ & * & A6 & $189 \pm 16.9$ & $*$ & A8 & $66 \pm 12.0^{a}$ & nt & & & nt \\
\hline
\end{tabular}

estuarine arrival $\left(\mathrm{T}_{\mathrm{s}}\right)$, and from 0 to $37 \mathrm{~d}$ during their stay in the estuary $\left(\mathrm{T}_{\mathrm{e}}\right)$. An analysis of variance indicated that mean $\mathrm{T}_{\mathrm{t}}, \mathrm{T}_{\mathrm{m}}$ and $\mathrm{T}_{\mathrm{s}}$ differed significantly among the 8 estuaries $(p<0.001) . T_{t}, T_{m}$ and $T_{s}$ were all positively correlated with total length $(p<0.001)$ (Fig. 5), indicating that the total length of glass eels depends on both $\mathrm{T}_{\mathrm{m}}$ and $\mathrm{T}_{\mathrm{s}}$.

Table 3 compares the means of $T_{t}, T_{m}$ and $T_{s}$ among the 8 estuaries. The mean $T_{t}$ of the northern group (Sites A1 to A3) was significantly lower than that of the southern group (Sites A4 to A8). Similarly, the mean $\mathrm{T}_{\mathrm{m}}$ in the north (A1 to A3) was also significantly lower than in the southern group (A5 to A8). The mean $T_{S}$ of A1 to A3 belonged to the same homogeneous group and were significantly lower than at A4 to A6. These data indicate that mean $\mathrm{T}_{\mathrm{t}}, \mathrm{T}_{\mathrm{m}}$ and $\mathrm{T}_{\mathrm{s}}$ tended to

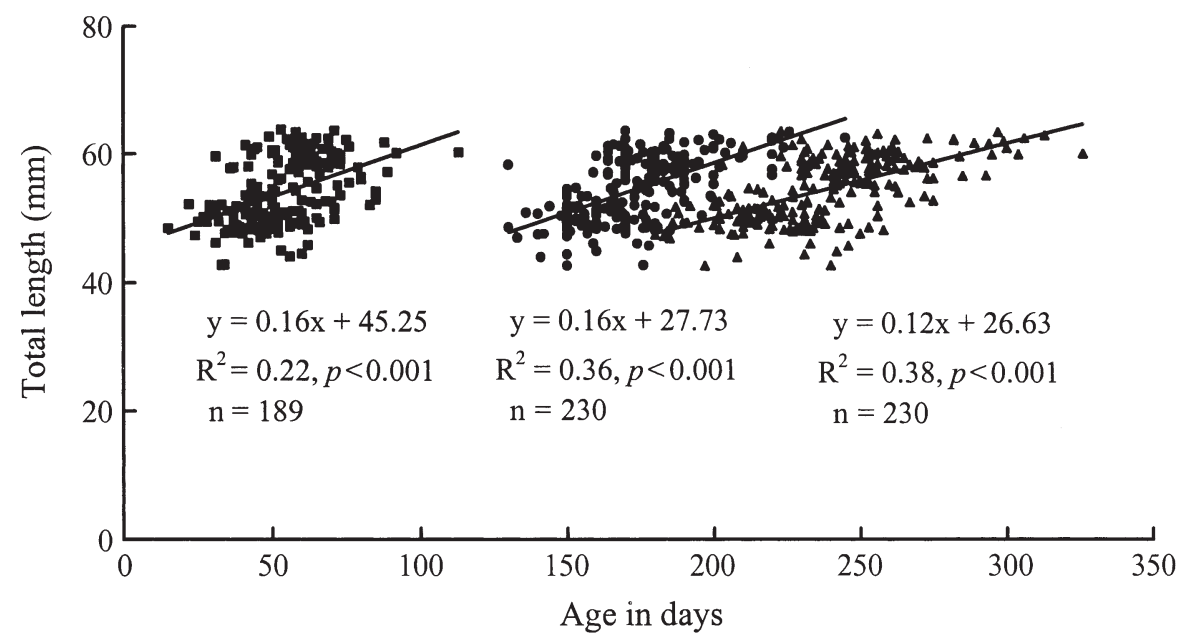

Fig. 5. Anguilla australis. Relationships between total length of glass eels and age at capture $\left(\mathrm{T}_{\mathrm{t}}, \boldsymbol{\Delta}\right)$, age of leptocephali at metamorphosis $\left(\mathrm{T}_{\mathrm{m}}, \boldsymbol{\bullet}\right)$ and period between metamorphosis and estuarine arrival $\left(\mathrm{T}_{\mathrm{s}} \mathbf{\square}\right) . \mathrm{n}=$ sample size increase from north to south. In other words, the ages of the glass eels $\left(T_{t}, T_{m}\right.$ and $\left.T_{s}\right)$ all increased with increasing distance from the spawning ground. In contrast, the mean residence time of glass eels in the estuaries $\left(\mathrm{T}_{\mathrm{e}}\right)$ was relatively longer at A1 and A3 than at the other sampling sites (Table 3). This was probably because the sampling sites A1 and A3 were 30 to $40 \mathrm{~km}$ further upstream than the other estuaries, necessitating a longer migration time.

\section{Growth rate of the otolith}

The otolith growth rate of the leptocephali $\left(G_{m}\right)$ was very similar for all groups, but a little faster in the north (e.g. Site A2) than in the south (e.g. Sites A6 and A7). This indicated that faster-growing leptocephali migrate to the north and slower-growing leptocephali to the south (Table 4). Similarly, the otolith growth rates of glass eels before entering the estuary $\left(\mathrm{G}_{\mathrm{s}}\right)$ were significantly faster at northern sites (A1 to A3) than at southern sites (A4 to A6).

\section{Hatching dates}

The estimated hatching dates of Anguilla australis extended from late August to early February for Australian samples, and mid October to middle January for New Zealand samples (Fig. 6). In addition, the hatching dates of glass eels recruiting to the same estuary at different dates overlapped considerably. 


\section{DISCUSSION}

\section{Age upon estuarine arrival in relation to otolith growth rate and age at metamorphosis}

We assumed that the growth increments in otoliths of Anguilla australis were deposited on a daily basis, as are those of A. japonica, A. rostrata and A. celebesensis, which have been validated (Umezawa et al. 1989, Martin 1995, Arai et al. 2000). The present study found that the Australiasian eel A. australis took approximately 7 to 9 mo to drift from the spawning grounds to the estuaries of Australia and New Zealand (Table 3), and metamorphosis from leptocephalus to glass eel occurred approximately 5 to 6 mo after hatching. Our estimates of age are similar to those of Arai et al. (1999c), who compared the ages of New Zealand glass eels collected at the same estuaries in 1996. This provides independent confirmation of the ageing technique.

Metamorphosis from the leptocephalus to the glass eel is thought to take place in the open ocean (Tzeng \& Tsai 1994, Antunes \& Tesh 1997). After metamorphosis, glass eels migrate from the open ocean into the coastal waters and thereafter invade freshwater rivers. The mean otolith growth rate of the leptocephalus stage $\left(G_{m}\right)$ was a little greater in the northern group than in the southern group. However, the mean age at metamorphosis from leptocephali to glass eel was ca 1 mo less in the northern group (Sites A1 to A3, $160 \pm 14.2$ to $161 \pm 12.6 \mathrm{~d}$ ) than in the southern group (e.g. Sites A5 and A6, $183 \pm 20.8$ and $189 \pm 16.9$ d: Table 3). This implies that those leptocephali metamorphosing early would escape from the ocean current earlier and recruit to the northern Australia. Conversely, those leptocephali metamorphosing late would continue to drift with the ocean current further south and recruit to southern Australia.
Since the samples were collected in different years (1996 to 1999), it is possible that varying environmental conditions including oceanic change such as current speed and direction may influence the recruitment of glass eels. To assess this, we compared our data from Albert River (Site A3) in 1997 with published data from the same sampling site in 1996 (Arai et al. 1999c). The mean age of glass eels at metamorphosis and estuarine arrival were $164 \pm 18.6 \mathrm{~d}$ and $208 \pm 17.4 \mathrm{~d}$ in the Arai et al. (1999c) study and $161 \pm 12.6 \mathrm{~d}$ and $217 \pm 16.6 \mathrm{~d}$ in the present study. This very close agreement of ages for different years indicates that interannual variability of age at metamorphosis and recruitment in the same estuary may be minor, and less than variability due to geographic differences.

\section{Effect of oceanic currents on larval dispersal}

The East Australian Current (EAC) originates from the South Equatorial Current (SEC) and flows along the eastern seaboard of Australia. Most researchers have assumed that leptocephali travel to Australia on the East Australian Current (Schmidt 1928, Cairns 1941, Sloane 1984, Jellyman 1987, Beumer \& Sloane 1990). The geographic cline in the ages of glass eels arriving in Australia found in the present study supports this assumption.

Based on the SEC speed of 0.5 to $0.6 \mathrm{~m} \mathrm{~s}^{-1}$ (Tchernia 1980) and active swimming of the larvae for only $16 \mathrm{~h}$ at night (Umezawa 1991), Arai et al. (1999c) calculated that the time needed for eel larvae to migrate $5000 \mathrm{~km}$ from their presumed spawning grounds (Jellyman 1987) to the eastern coasts of Australia was approximately 145 to $173 \mathrm{~d}$. Since larvae passively drift with oceanic currents for $24 \mathrm{~h}$ a day, a period of $16 \mathrm{~h}$ drift overestimates the time required to reach the continent. Furthermore, Jellyman calculated the distance from

Table 4. Anguilla australis. Homogeneity test $(\mathrm{HG})$ for otolith radius $\left(\mathrm{R}_{\mathrm{m}}\right.$ and $\left.\mathrm{R}_{\mathrm{s}}\right)$ and otolith growth rate $\left(\mathrm{G}_{\mathrm{m}}\right.$ and $\left.\mathrm{G}_{\mathrm{s}}\right)(\mathrm{mean} \pm \mathrm{SD})$ of glass eels collected from 8 estuaries (A1 to A8). Abbreviations are defined in 'Materials and methods'. Asterisks shared between estuaries indicate they belong to same homogeneous group $(p<0.05)$. Sample size for each site is shown in parentheses in Table 1. nt: data excluded from homogeneity test (see Table 3 legend)

\begin{tabular}{|c|c|c|c|c|c|c|c|c|c|c|c|}
\hline \multicolumn{3}{|c|}{$\mathrm{R}_{\mathrm{m}}(\mu \mathrm{m})$} & \multicolumn{3}{|c|}{$\mathrm{G}_{\mathrm{m}}\left(\mu \mathrm{m} \mathrm{d}^{-1}\right)$} & \multicolumn{3}{|c|}{$\mathrm{R}_{\mathrm{s}}(\mu \mathrm{m})$} & \multicolumn{3}{|c|}{$\mathrm{G}_{\mathrm{s}}\left(\mu \mathrm{m} \mathrm{d} \mathrm{d}^{-1}\right)$} \\
\hline Site & Mean \pm SD & $\mathrm{HG}$ & Site & Mean \pm SD & $\mathrm{HG}$ & Site & Mean \pm SD & $\mathrm{HG}$ & Site & Mean \pm SD & $\mathrm{HG}$ \\
\hline A3 & $81 \pm 6.1$ & $*$ & A7 & $0.50 \pm 0.03$ & * & A1 & $42 \pm 11.7$ & * & A2 & $1.05 \pm 0.22$ & $*$ \\
\hline A1 & $81 \pm 6.6$ & $*$ & A6 & $0.51 \pm 0.05$ & $*$ & A3 & $43 \pm 8.5$ & $*$ & A3 & $1.03 \pm 0.23$ & * \\
\hline $\mathrm{A} 2$ & $82 \pm 5.9$ & $* *$ & A5 & $0.51 \pm 0.05$ & $* *$ & A5 & $45 \pm 8.1$ & $*$ & A1 & $0.98 \pm 0.2$ & $*$ \\
\hline A4 & $84 \pm 6.9$ & $* * *$ & A3 & $0.52 \pm 0.04$ & $* *$ & A6 & $45 \pm 6.4$ & $*$ & A5 & $0.81 \pm 0.14$ & $*$ \\
\hline $\mathrm{A} 7$ & $88 \pm 4.8$ & $* * *$ & A8 & $0.53 \pm 0.03$ & $* *$ & $\mathrm{~A} 2$ & $46 \pm 7.4$ & $*$ & A4 & $0.76 \pm 0.18$ & $*$ \\
\hline A5 & $89 \pm 11.6$ & $* *$ & A4 & $0.53 \pm 0.04$ & $* *$ & A4 & $49 \pm 8.1$ & $*$ & A6 & $0.75 \pm 0.13$ & $*$ \\
\hline A8 & $89 \pm 4.2$ & $* *$ & A1 & $0.53 \pm 0.04$ & $* *$ & A7 & $53 \pm 8.3^{\mathrm{a}}$ & $\mathrm{nt}$ & A7 & $0.75 \pm 0.12^{\mathrm{a}}$ & nt \\
\hline A6 & $91 \pm 9.2$ & $*$ & A2 & $0.54 \pm 0.05$ & $*$ & A8 & $55 \pm 7.8^{\mathrm{a}}$ & $\mathrm{nt}$ & A8 & $0.83 \pm 0.12^{\mathrm{a}}$ & $\mathrm{nt}$ \\
\hline
\end{tabular}



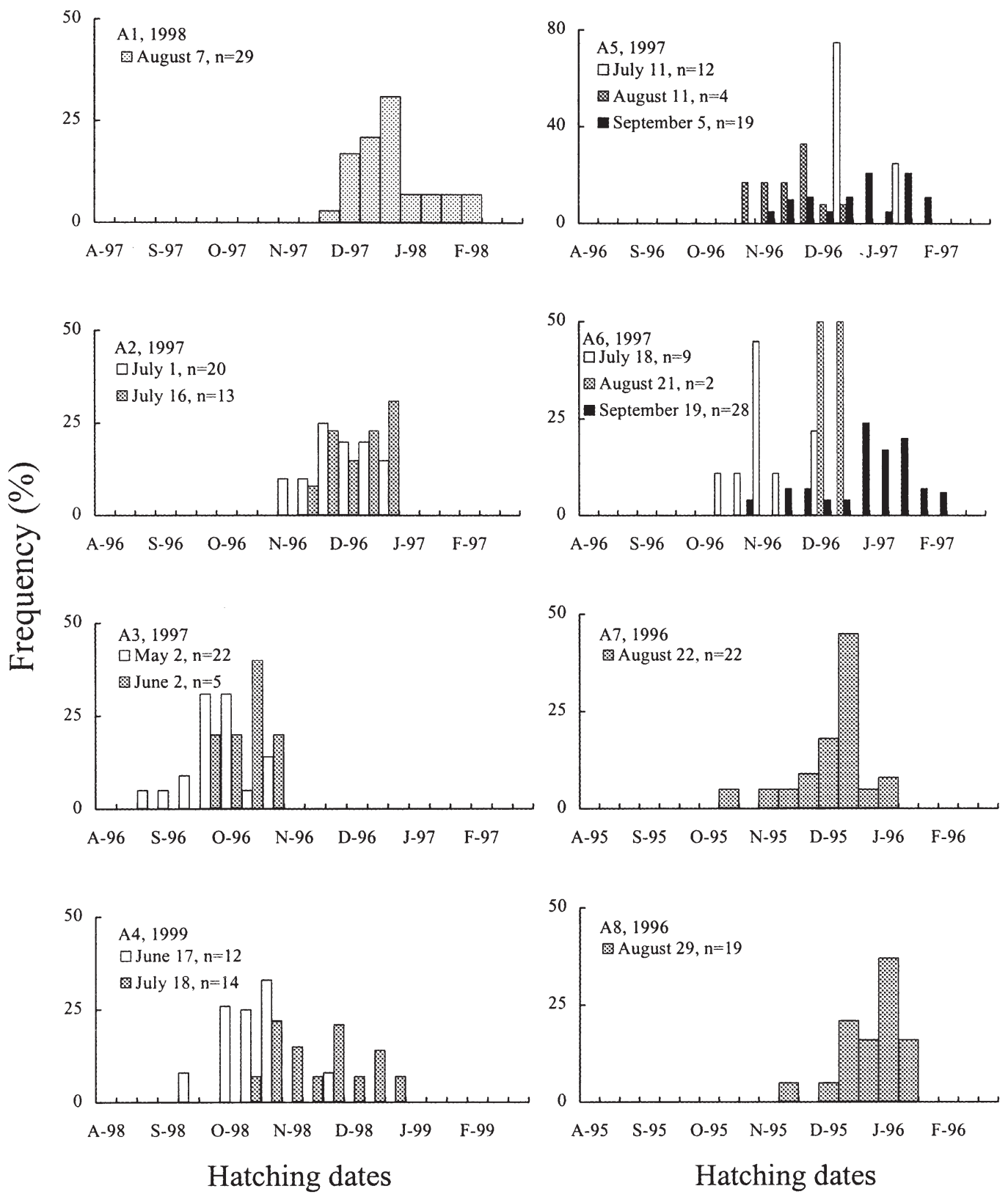

Fig. 6. Anguilla australis. Frequency distribution of hatching dates (back-calculated from the sampling dates and ages) of glass eels collected from the 8 estuaries (Sites A1 to A8 are shown in Fig. 1). $\mathrm{n}=$ sample size

the spawning grounds to Tasmania to be $7000 \mathrm{~km}$. Hence, the distance from the spawning grounds to northern Australia (Sites A1 to A3) should be $6000 \mathrm{~km}$. Accordingly, approximately 116 to 139 d would be required to transport eel larvae from the spawning area to northern Australia, based on the speed of the SEC ( 0.5 to $0.6 \mathrm{~m} \mathrm{~s}^{-1}$ ) and a whole-day drift ( $\left.24 \mathrm{~h}\right)$. This estimate was slightly lower than the ages of eels at metamorphosis from leptocephalus to glass eel at Sites A1 to A3 (Table 3). A possible explanation is that the eel larvae may have been indirectly transported by complex oceanic currents from their spawning ground to the continent.

The ages of the eels at metamorphosis from leptocephalus to glass eel were ca 1 mo greater in the southern than in the northern group (Table 3). During this period, the leptocephali of the southern group would continue to drift on the EAC to southern Australia, while the leptocephali of the northern group would already have metamorphosed to glass eels and have recruited to coastal waters. The difference in the mean ages of leptocephali at metamorphosis to glass eels 
was $29 \mathrm{~d}$ among the 6 estuaries in Australia. The average velocity of the EAC is $0.3 \mathrm{~m} \mathrm{~s}^{-1}$ (Bramwell 1977), probably reaching speeds as high as $0.52 \mathrm{~m} \mathrm{~s}^{-1}$ (Wyrtki 1962). Based on current speed, the EAC could disperse the leptocephali a distance of between 751 and $1303 \mathrm{~km}$ over this $29 \mathrm{~d}$ period. This distance approximately coincides with the geographic range of the glass eels from the northern to southern estuaries (Sites A3 to A6), and indicates that the EAC plays an important role in transporting the eel larvae from northern Australia to the south.

From about $18^{\circ} \mathrm{S}$, the EAC flows generally southward along the east Australian coast, then divides at Latitude 33 to $34^{\circ} \mathrm{S}$. A weak branch flows to the south as anticyclonic warm-core eddies (Hamon 1965). The main branch flows offshore to the northeast or north, still as a narrow swift current (Hamon 1965). Further offshore, the remainder of this branch crosses the Tasman Sea southeastward in the general direction of New Zealand, following the Tasman Front (Boland \& Church 1981, Gresswell \& Legeckis 1986). Based on this circulation pattern, Cairns (1941), Castle (1969) and Aoyama et al. (1999) suggested that the leptocephali of Anguilla australis drift with the EAC to the western coast of New Zealand. If the eel larvae are transported by the EAC to the western coasts of New Zealand, the leptocephali must drift at least $1500 \mathrm{~km}$, crossing the Tasman Sea. The surface speed at the Tasman Front is $0.14 \mathrm{~m} \mathrm{~s}^{-1}$ (Wyrtki 1962). To drift a distance of $1500 \mathrm{~km}$ at speed of $0.14 \mathrm{~m} \mathrm{~s}^{-1}$ requires approximately $120 \mathrm{~d}$. In practice, the ages of leptocephali at metamorphosis $\left(\mathrm{T}_{\mathrm{m}}\right)$ from the most adjacent transTasman sites (A5 and A7) differed by an average of only $8 \mathrm{~d}$. Thus, it is highly unlikely that recruitment of glass eels to New Zealand is via the east coast of Australia. Furthermore, information on arrival times and sizes of glass eels suggest that arrival in New Zealand is more likely to be from the north than the west (Jellyman 1987, Jellyman et al. 1999, Chisnall et al. 2000). Another possible migration route is transportation by the southwest-flowing portion of the SEC (Jellyman 1987). To validate this possible route, an intensive and successive collection of leptocephali would be required. Likewise, data on ages of glass eels from the north of New Zealand would help confirm whether recruitment to New Zealand is from the north, as suggested by Jellyman (1987) and Jellyman et al. (1999).

\section{Factors affecting duration of glass eel stage}

We found that the glass eels from southern Australia and New Zealand spent more time in coastal waters (Table 3) than the northern group. The magnitude and direction of the EAC might influence the timing of glass eel recruitment. The strong EAC flows continuously and frequently spreads across the continental shelf between 27 and $33^{\circ} \mathrm{S}$ (Huyer et al. 1988, Middleton et al. 1994). Hence, the EAC off Sites A1 to A3 may carry the glass eels very close to the coast and shorten the time for recruitment to the estuaries. However, offshore at Latitude $34^{\circ} \mathrm{S}$, the EAC becomes intermittent and weak, forming irregular and complex eddies. If glass eels were entrained into the complex eddy or northward/northeastward return current (Hamon 1965), they would need additional time to reach the coasts. This might be the reason why the glass eels of the Sites A4 to A5 had a longer residence time in coastal waters.

Growth rate provides another explanation for the difference in the duration of the glass eel stage $\left(G_{s}\right)$ among sampling sites. A lower otolith growth rate was found in southern Australia (Sites A4 to A6) and New Zealand (Table 4) than in the north. In winter, the coastal water temperature in southern Australia and New Zealand $\left(13^{\circ} \mathrm{C}\right.$ at $\left.35^{\circ} \mathrm{S}\right)$ is lower than in northern Australia $\left(20^{\circ} \mathrm{C}\right.$ at $25^{\circ} \mathrm{S}$ : Tchernia 1980$)$. Low temperature and slower growth rate of the glass eels might be one of the reasons causing a delay in recruitment.

\section{Conclusion}

The size, age composition and growth rate of otoliths indicated that glass eels recruiting into Australian waters are comprised of 2 groups. The timing of metamorphosis from leptocephalus to glass eel and transportation by the SEC/EAC play an important role in determining the destination of the glass eels. On the other hand, glass eels recruiting to New Zealand probably utilize a different route from the Australian group, since the difference in age at metamorphosis between the leptocephali sampled in Australia and those sampled in New Zealand was not sufficient for the leptocephali to have drifted across the Tasman Sea from eastern Australia to the western coast of New Zealand.

Acknowledgements. This study was financially supported by the National Science Council (NSC89-2611-B-002-004), Republic of China. The authors thank Dr L. Mckinnon for providing specimens from Victoria, Miss C. Y. Lin for assistance in taking SEM photographs, Miss S. Y. Tsai for electron probe microanalysis and the anonymous reviewers for helpful comments.

\section{LITERATURE CITED}

Antunes C, Tesh FW (1997) A critical consideration of the metamorphosis zone when identifying daily rings in otoliths of European eel, Anguilla anguilla (L.). Ecol Freshw Fish 6:102-107

Aoyama J, Mochioka N, Otake T, Ishikawa S, Kawakami Y, Castle P, Nishida M, Tsukamoto K (1999) Distribution and 
dispersal of anguillid leptocephali in the western Pacific Ocean revealed by molecular analysis. Mar Ecol Prog Ser 188:193-200

Arai T, Otake T, Tsukamoto K (1997) Drastic changes in otolith microstructure and microchemistry accompanying the onset of metamorphosis in the Japanese eel Anguilla japonica. Mar Ecol Prog Ser 161:17-22

Arai T, Limbong D, Otake T, Tsukamoto K (1999a) Metamorphosis and inshore migration of tropical eels, Anguilla spp., in the Indo-Pacific. Mar Ecol Prog Ser 182:283-293

Arai T, Otake T, Jellyman DJ, Tsukamoto K (1999b) Differences in the early life history of the Australasian shortfin eel Anguilla australis from Australia and New Zealand, as revealed by otolith microstructure and microchemistry. Mar Biol 135:381-389

Arai T, Otake T, Limbong D, Tsukamoto K (1999c) Early life history and recruitment of the tropical eel, Anguilla bicolor pacifica, as revealed by otolith microstructure and microchemistry. Mar Biol 133:319-326

Arai T, Limbong D, Otake T, Tsukamoto K (2000) Validation of otolith daily increments in the tropical eel Anguilla celebesensis. Can J Zool 78:1078-1084

Beumer J, Sloane R (1990) Distribution and abundance of glass-eels Anguilla spp. in East Australian waters. Int Revue Gesamten Hydrobiol 75:721-736

Boland FM, Church JA (1981) The East Australian Current 1978. Deep-Sea Res 28A:937-957

Bramwell M (ed) (1977) The atlas of the oceans. Mitchell Beazley, London

Cairns D (1941) Life-history of the two species of New Zealand freshwater eel. Part 1. Taxonomy, age and growth, migration and distribution. N Z J Sci Technol Sect B 23:53b-72b

Castle PHJ (1963) Anguillid leptocephali in the southwest Pacific. Zoology Publ, Vic Univ Wellingt 33:1-14

Castle PHJ (1969) Early life history and general distribution of eels. In: Campbell JS (ed) Report on eel seminar. New Zealand Fishing Industry Board, Wellington, p 14-18

Cheng PW, Tzeng WN (1996) Timing of metamorphosis and estuarine arrival across the dispersal range of the Japanese eel Anguilla japonica. Mar Ecol Prog Ser 131:87-96

Chisnall BL, Jellyman DJ, Bonnett ML, Sykes JRE (2000) Studies on glass eels in New Zealand. NIWA, Wellington, Water and Atmosphere 8(4):21-22

Dijkstra LH, Jellyman DJ (1999) Is the subspecies classification of the freshwater eels Anguilla australis australis Richardson and A. a. schmidtii Phillipps still valid? Mar Freshw Res 50:261-263

Ege V (1939) A revision of the genus Anguilla Shaw. A systematic, phylogenetic and geographical study. Dana-Rep 3:1-256

Gresswell GR, Legeckis R (1986) Eddies off southeastern Australia. Deep-Sea Res 33:1527-1562

Hamon BV (1965) The East Australian Current, 1960-1964 Deep-Sea Res 12:899-921

Huyer A, Smith RL, Stabeno PJ, Church JA, White NJ (1988) Currents off south-eastern Australia: results from the Australian coastal experiment. Aust J Mar Freshw Res 39: 245-288

Jellyman DJ (1987) Review of the marine life history of Aus-

Editorial responsibility: Otto Kinne (Editor), Oldendorf/Luhe, Germany tralian temperate species of Anguilla. Am Fish Soc Symp $1: 276-285$

Jellyman DJ, Chisnall BL, Bonnett ML, Sykes JRE (1999) Seasonal arrival patterns of juvenile freshwater eels (Anguilla spp.) in New Zealand. N Z J Mar Freshw Res 33:249-262

Kawakami Y, Mochioka N, Morishita K, Toh H, Nakazono A (1998) Determination of the freshwater mark in otoliths of Japanese eel elvers using microstructure and Sr/Ca ratios. Environ Biol Fish 53:421-427

Martin MH (1995) Validation of daily growth increments in otoliths of Anguilla rostrata (Lesueur) elvers. Can J Zool 73:208-211

Middleton JH, Coutis P, Griffin DA, Macks A, McTaggart A, Merrifield MA, Nippard GJ (1994) Circulation and water mass characteristics of the Southern Great Barrier Reef. Aust J Mar Freshw Res 45:1-18

Otake T, Ishii T, Nakahara M, Nakamura R (1994) Drastic changes in otolith strontium/calcium ratios in leptocephali and glass eels of Japanese eel Anguilla japonica. Mar Ecol Prog Ser 112:189-193

Pannella G (1971) Fish otolith: daily growth layers and periodical patterns. Science 173:1124-1127

Schmidt J (1928) The freshwater eels of Australia with some remarks on the shortfin species of Anguilla. Rec Aust Mus 16:179-210

Sloane RD (1984) Invasion and upstream migration by glasseels of Anguilla australis australis Richardson and A. reinhardtii Steindachner in Tasmanian freshwater streams. Aust J Mar Freshw Res 35:47-59

Strubberg AC (1913) The metamorphosis of elvers as influenced by outward conditions. Medd Kommn Havunders Ser Fiskeri 4(3):1-11

Tchernia P (1980) Descriptive regional oceanography. Pergamon Mar Ser 3. Pergamon Press, Oxford.

Tzeng WN (1990) Relationship between growth rate and age at recruitment of Anguilla japonica elvers in a Taiwan estuary as inferred from otolith growth increments. Mar Biol 107:75-81

Tzeng WN, Tsai YC (1994) Changes in otolith microchemistry of the Japanese eel, Anguilla japonica, during its migration from the ocean to the rivers of Taiwan. J Fish Biol 45: 671-683

Umezawa A (1991) Early life history and recruitment mechanism of the eel, Anguilla japonica. PhD thesis, The University of Tokyo, Tokyo

Umezawa A, Tsukamoto K, Tabeta O, Yamakawa H (1989) Daily growth increments in the larval otolith of the Japanese eel Anguilla japonica. Jpn J Ichthyol 35:440-444

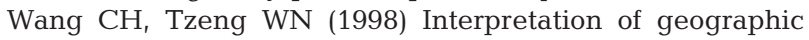
variation in size of American eel Anguilla rostrata elvers on the Atlantic coast of North America using their life history and otolith ageing. Mar Ecol Prog Ser 168:35-43

Wang $\mathrm{CH}$, Tzeng WN (2000) The timing of metamorphosis and growth rates of American and European eel leptocephali: a mechanism of larval segregative migration. Fish Res (Amst) 1019:1-15

Wyrtki K (1962) Geopotential topographies and associated circulation in the western south Pacific Ocean. Aust J Mar Freshw Res 13:89-105

Submitted: May 10, 2000; Accepted: September 14, 2000

Proofs received from author(s): August 8, 2001 